Article

\title{
Effect of Calcium and Potassium on Antioxidant System of Vicia faba L. Under Cadmium Stress
}

\author{
Manzer H. Siddiqui *, Mohamed H. Al-Whaibi, Ahmed M. Sakran, Mohammed O. Basalah and \\ Hayssam M. Ali
}

Department of Botany and Microbiology, College of Science, King Saud University, Riyadh, Saudi Arabia; E-Mails: mwhaibi@ksu.edu.sa (M.H.A.-W.); ahmed_sakran@yahoo.com (A.M.S.); basalah@ksu.edu.sa (M.O.B.); hayssam77@hotmail.com (H.M.A.)

* Author to whom correspondence should be addressed; E-Mail: manzerhs@yahoo.co.in; Tel.: +966-14675872; Fax: +966-14675833.

Received: 5 April 2012; in revised form: 21 May 2012 / Accepted: 22 May 2012 /

Published: 29 May 2012

\begin{abstract}
Cadmium (Cd) in soil poses a major threat to plant growth and productivity. In the present experiment, we studied the effect of calcium $\left(\mathrm{Ca}^{2+}\right)$ and/or potassium $\left(\mathrm{K}^{+}\right)$on the antioxidant system, accumulation of proline (Pro), malondialdehyde (MDA), and content of photosynthetic pigments, cadmium $(\mathrm{Cd})$ and nutrients, i.e., $\mathrm{Ca}^{2+}$ and $\mathrm{K}^{+}$in leaf of Vicia faba L. (cv. TARA) under Cd stress. Plants grown in the presence of Cd exhibited reduced growth traits [root length (RL) plant ${ }^{-1}$, shoot length (SL) plant ${ }^{-1}$, root fresh weight (RFW) plant $^{-1}$, shoot fresh weight (SFW) plant ${ }^{-1}$, root dry weight (RDW) plant ${ }^{-1}$ and shoot dry weight (SDW) plant ${ }^{-1}$ ] and concentration of $\mathrm{Ca}^{2+}, \mathrm{K}^{+}$, Chlorophyll (Chl) $a$ and Chl $b$ content, except content of MDA, Cd and (Pro). The antioxidant enzymes [peroxidase (POD) and superoxide dismutase (SOD)] slightly increased as compared to control under $\mathrm{Cd}$ stress. However, a significant improvement was observed in all growth traits and content of $\mathrm{Ca}^{2+}, \mathrm{K}^{+}, \mathrm{Chl} a, \mathrm{Chl} b$,Pro and activity of antioxidant enzymes catalase (CAT), POD and SOD in plants subjected to $\mathrm{Ca}^{2+}$ and/or $\mathrm{K}^{+}$. The maximum alleviating effect was recorded in the plants grown in medium containing $\mathrm{Ca}^{2+}$ and $\mathrm{K}^{+}$together. This study indicates that the application of $\mathrm{Ca}^{2+}$ and/or $\mathrm{K}^{+}$had a significant and synergistic effect on plant growth. Also, application of $\mathrm{Ca}^{2+}$ and/or $\mathrm{K}^{+}$was highly effective against the toxicity of $\mathrm{Cd}$ by improving activity of antioxidant enzymes and solute that led to the enhanced plant growth of faba bean plants.
\end{abstract}


Keywords: antioxidant; faba bean; heavy metal; nutrient content; photosynthetic pigments

\section{Introduction}

Increasing cadmium $(\mathrm{Cd})$ in soil is an enormous constraint for agriculture worldwide. $\mathrm{Cd}$ is a highly toxic metal that causes deleterious effects on plants, and limits crop productivity [1]. Cd is commonly released into the arable soil from industries, energy, municipal sources and farming practices, and has been ranked No. 7 among the top 20 toxins [2]. Cd is easily taken up by plant roots and transported to the leaves through xylem [3]. Most plants are sensitive to low concentration of $\mathrm{Cd}$, which disturb the physiological and molecular mechanisms by which plants carry out adaptive response to the environmental stresses. Therefore, it is important to understand the physiological mechanisms by which plants could perform normally under abiotic stress. Cd causes inhibition of physiological process such as photosynthesis, respiration, cell elongation, plant water relationship and assimilation of nitrogen, sulphur and phosphate, resulting in poor growth and development of plants $[1,4]$. Cd also disturbs the ion homeostasis in plants. The presence of $\mathrm{Cd}$ in soil perturbs the absorption of nutrients such as $\mathrm{Ca}, \mathrm{Mg}, \mathrm{K}, \mathrm{N}, \mathrm{P}, \mathrm{Fe}, \mathrm{Mn}, \mathrm{Cu}, \mathrm{Zn}$ and $\mathrm{Ni}$ [5-7]. However, the mechanisms involved in its toxicity as well as the cell response against the metal have not been well established $[8,9]$.

Application of nutrients has become indispensable factor that has a broad influence on the growth and metabolism of plants under the condition of different soil environments [10]. One possible approach to minimize the $\mathrm{Cd}$ stress on plant productivity is through the addition of mineral nutrients, of which potassium $\left(\mathrm{K}^{+}\right)$has an outstanding role in plant growth and development. $\mathrm{K}^{+}$is the most abundant cation in plants (up to $10 \%$ on dry weight basis) [11]. It is present in high concentration in cytosol and chloroplast, and activates many enzymes by stabilizing the $\mathrm{pH}$ between 7 and 8 , by changing the enzymatic conformation, and also by binding the enzymes surface [12,13]. A large number of enzymes are either completely dependent on or stimulated by $\mathrm{K}^{+}$; more than 50 enzymes are activated by $\mathrm{K}^{+}$[14]. It induces the cell elongation and maintains osmoregulation. $\mathrm{K}^{+}$-assimilation is an essential pathway for offsetting the Cd stress in plants by giving stimulatory influence of synthesis of protein, soluble carbohydrates and soluble nitrogen containing compounds (12), hence, these solutes may play a role in osmotic adjustment. Besides $\mathrm{K}^{+}$, calcium $\left(\mathrm{Ca}^{2+}\right)$ has a significant role in alleviating the inhibitory effect of $\mathrm{Cd}$ on growth and physiological processes [15,16], and also increasing antioxidant enzyme activities, and in reducing lipid peroxidation of cell membranes $[16,17] . \mathrm{Ca}^{2+}$ plays an important role in heavy metal detoxification and in tolerance of plant to biotic and abiotic stress [18-20]. $\mathrm{Ca}^{2+}$ has also been shown to stabilize cell membrane surfaces, influence the $\mathrm{pH}$ of cells and prevent solute leakage from cytoplasm [21]. It is required for various structural roles in the cell wall and membranes; it is a counteraction for inorganic and organic anions in the vacuole, and the cytosolic. $\mathrm{Ca}^{2+}$ concentration is one of many cellular network parameters orchestrating complex cellular signaling coordinating responses to numerous developmental cues and environmental challenges [20,22,23].

Several studies have reported that the application of $\mathrm{Ca}^{2+}$ inhibits the $\mathrm{K}^{+}$absorption or transportation in plants [24-26]. However, inhibitory effects of $\mathrm{Ca}^{2+}$ on $\mathrm{K}^{+}$absorption are temporary 
and time-dependent because $\mathrm{Ca}^{2+}$ is needed to maintain the integrity of cellular membranes and of selective ion transport mechanisms by which $\mathrm{K}^{+}$is actively absorbed [17,21,25,27,28]. Research has also shown that $\mathrm{Ca}^{2+}$ can significantly promote the absorption of $\mathrm{K}^{+}$[25]. Moreover, some research has been done on the interaction between nutrients [29-31] and also on the influence of nutrients under heavy metals stress [32-35]. However, the mechanism involved in absorption and transport of heavy metals in plants is still unclear related to the soil environment [10]. Therefore, it is important to study the interactions between nutrients and heavy metals. However, scanty information is available on the efficacy of $\mathrm{Ca}^{2+}$ and $\mathrm{K}^{+}$in offsetting the Cd stress in plants. Thus, we focused on $\mathrm{Ca}^{2+}$ and $\mathrm{K}^{+}$as possible inducers in the tolerance of faba bean to Cd stress. The major objectives of our study were to determine the interactive efficiency of $\mathrm{Ca}^{2+}$ and $\mathrm{K}^{+}$treatments in restoring the metabolic alterations resulting from $\mathrm{Cd}$ stress in faba bean.

\section{Results}

The significant changes of growth parameters in faba bean plants subjected to $\mathrm{Ca}^{2+}$ and/or $\mathrm{K}^{+}$under $\mathrm{Cd}$ stress and normal conditions are shown in Figure 1A-C. Application of $\mathrm{Ca}^{2+}$ and $\mathrm{K}^{+}$individually as well as in combination improved root length (RL) plant $^{-1}$, shoot length (SL) plant ${ }^{-1}$, root fresh weight (RFW) plant ${ }^{-1}$, shoot fresh weight (SFW) plant $^{-1}$, root dry weight (RDW) plant ${ }^{-1}$ and shoot dry weight (SDW) plant ${ }^{-1}$ ], as compared with the controls. However, combined application of $\mathrm{Ca}^{2+}$ and $\mathrm{K}^{+}$ showed more enhancing effect on all growth traits than individual treatment. Application of $\mathrm{Cd}$ inhibited all growth attributes of faba bean. However, the subsequent treatment of Cd-stressed plants with $\mathrm{Ca}^{2+}$ or $\mathrm{K}^{+}$alone as well as in combination alleviated the adverse effect of $\mathrm{Cd}$ on faba bean and caused a considerable improvement of RL, SL, SFW, RFW, SDW, and RDW. The combined application of $\mathrm{Ca}^{2+}$ and $\mathrm{K}^{+}$had maximum alleviating effect of $\mathrm{Cd}$ toxicity on all growth characteristics when compared with $\mathrm{Ca}^{2+}$ and $\mathrm{K}^{+}$supplied alone. In contrast, combined application of $\mathrm{Ca}^{2+}$ and $\mathrm{K}^{+}$ showed parity with the application of $\mathrm{Ca}^{2+}$ alone for SFW and RFW.

Figure 1D reveals that application of $\mathrm{Ca}^{2+}$ and $\mathrm{K}^{+}$alone as well as together significantly increased the chlorophyll (Chl) $a$ and $\mathrm{Chl} b$ as compared to the control under normal conditions. The combined application of $\mathrm{Ca}^{2+}$ and $\mathrm{K}^{+}$exhibited maximum value for both $\mathrm{Chl} a$ and $\mathrm{Chl} b$ when compared with individual application of $\mathrm{Ca}^{2+}$ and $\mathrm{K}^{+}$, under normal conditions. However, presence of $\mathrm{Cd}$ in growth medium suppressed both the photosynthetic pigments. Application of $\mathrm{Ca}^{2+}$ and/or $\mathrm{K}^{+}$significantly enhanced Chl $a$ and $\mathrm{Chl} b$ under stress. Moreover, application of $\mathrm{Ca}^{2+}$ and $\mathrm{K}^{+}$together was found to be more effective in alleviating the adverse effect of Cd stress on Chl $a$ and $\mathrm{Chl} b$. 
Figure 1. Ameliorating effect of calcium and potassium on shoot and root length (A), shoot fresh weight (FW) and root FW (B), shoot dry weight (DW) and root DW (C) and Chl $a$ and Chl $b$ (D) of faba bean plants under Cd stress. Bars followed by the same letters show no statistical difference at $p<0.05$ (Duncan Multiple Range Test). Average of four determinations are presented with bars indicating SE.
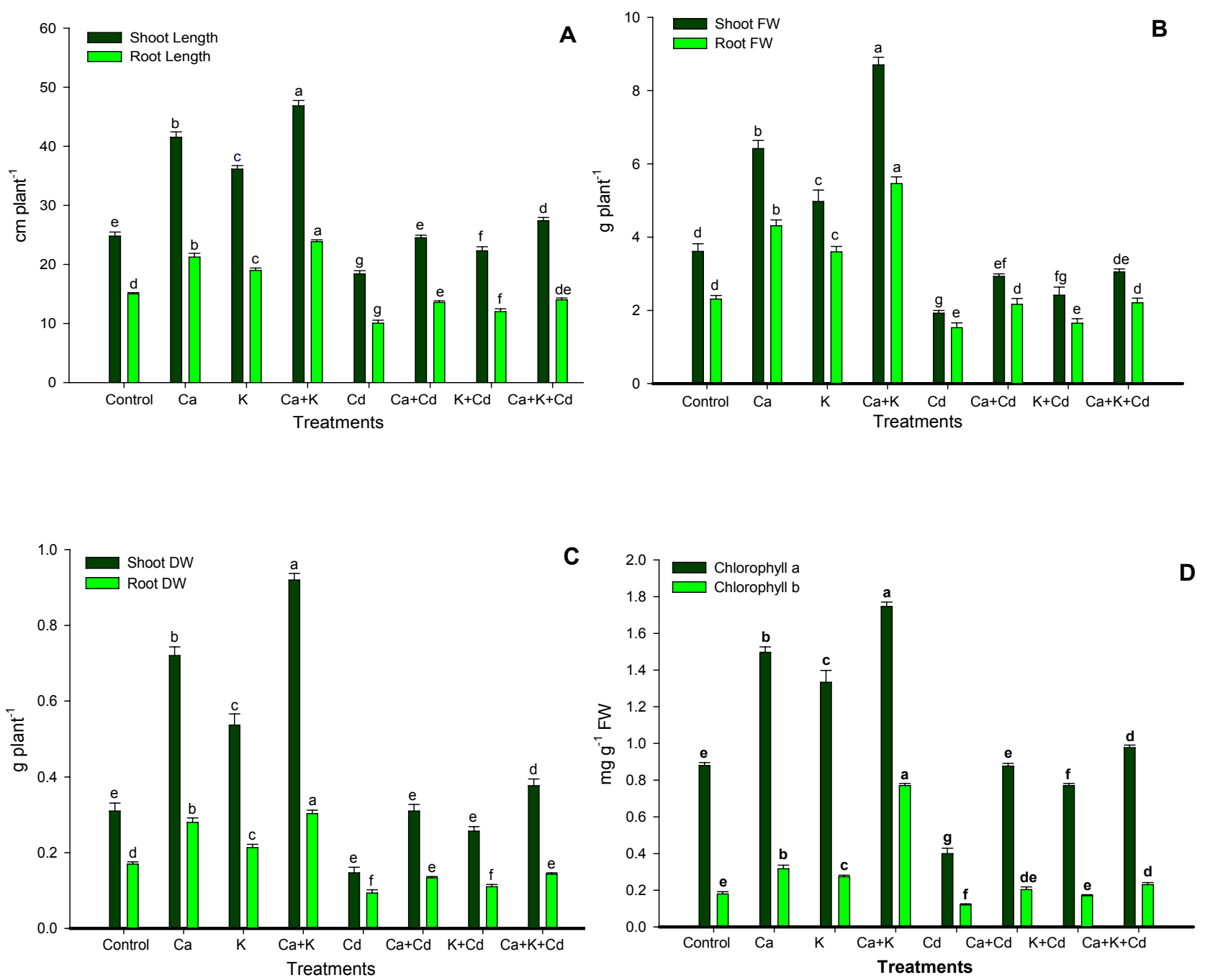

Figure 2A showed that $\mathrm{Cd}$ supplied in growth medium triggered accumulation of MDA, when compared with control. In contrast, under normal conditions, application of $\mathrm{Ca}^{2+}$ and/or $\mathrm{K}^{+}$inhibited accumulation as compared to the control. However, application of $\mathrm{Ca}^{2+}$ and $\mathrm{K}^{+}$alone as well as in combination arrested the ill effect of $\mathrm{Cd}$ up to a considerable limit by decreasing the accumulation of MDA in the leaf of faba bean plants. Under stress, the lowest accumulation of MDA was recorded in the plants that received $\mathrm{Ca}^{2+}$ and $\mathrm{K}^{+}$together. 
Figure 2. Ameliorating effect of calcium and potassium on MDA content (A), Cd content (B), $\mathrm{Ca}^{2+}$ and $\mathrm{K}^{+}$content $(\mathbf{C})$ and Pro content (D) of faba bean plants under Cd stress. Bars followed by the same letters show no statistical difference at $p<0.05$ (Duncan Multiple Range Test). Average of four determinations are presented with bars indicating SE.
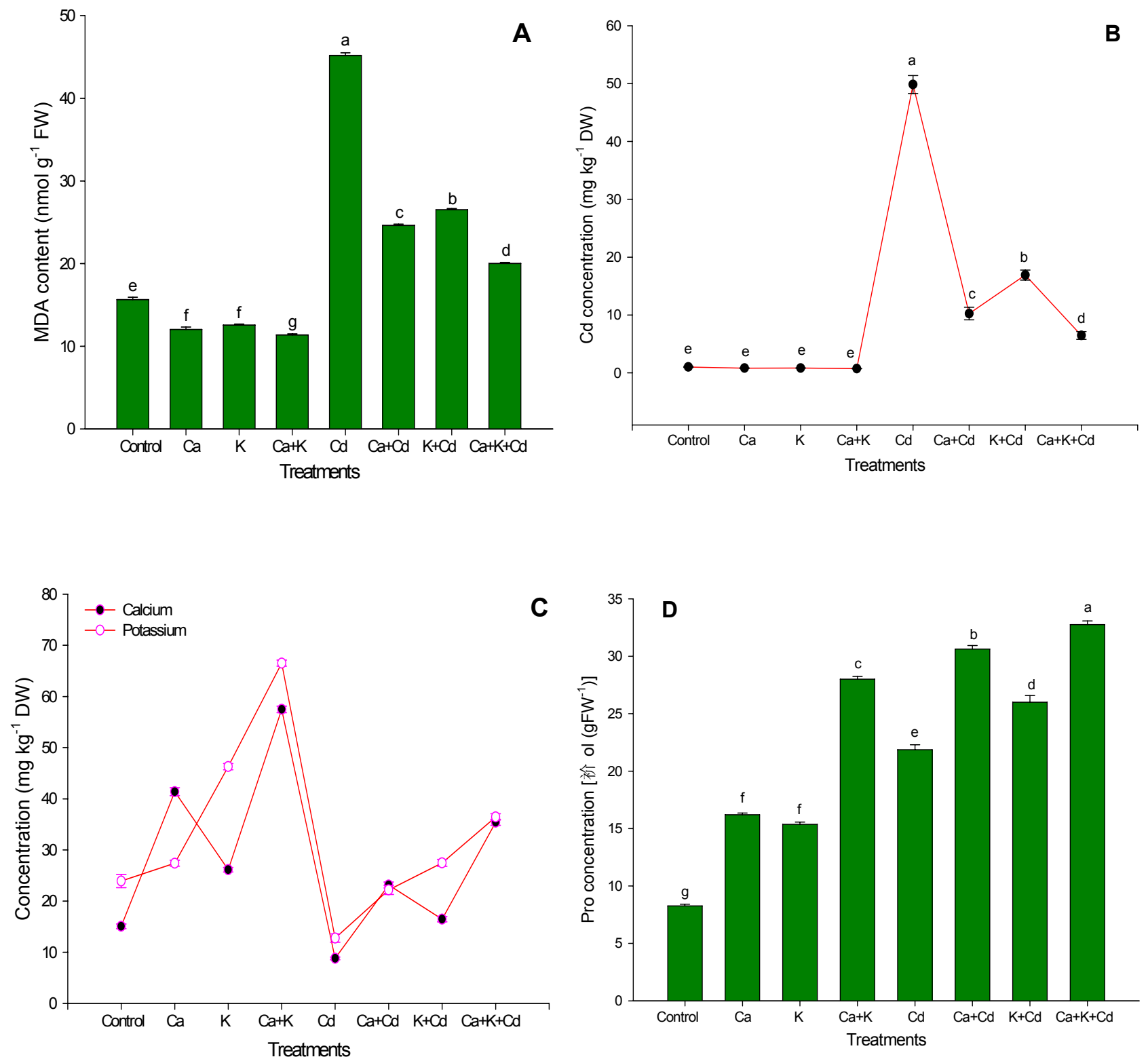

Application of $\mathrm{Cd}$ increased the highest content of $\mathrm{Cd}$ in leaves as compared with control and other treatments (Figure 2B). However, under Cd stress, application of $\mathrm{Ca}^{2+}$ and $\mathrm{K}^{+}$alone was found to be effective in suppressing leaf-Cd concentration, but maximum inhibition of $\mathrm{Cd}$ content was recorded in plants fed with the combined $\mathrm{Ca}^{2+}$ and $\mathrm{K}^{+}$application. The presence of $\mathrm{Cd}$ in growth medium suppressed both the content of both nutrients in the leaf. However, application of $\mathrm{Ca}^{2+}$ and $\mathrm{K}^{+}$alone as well as in combination increased leaf- $\mathrm{Ca}^{2+}$ and $\mathrm{K}^{+}$content under normal as well as stress conditions. Application of $\mathrm{Ca}^{2+}$ and $\mathrm{K}^{+}$individually was found to be effective in improving the content of 
leaf- $\mathrm{Ca}^{2+}$ and $\mathrm{K}^{+}$, but degree of efficiency of combined application of $\mathrm{Ca}^{2+}$ and $\mathrm{K}^{+}$in alleviating the adverse effect of $\mathrm{Cd}$ stress on leaf- $\mathrm{Ca}^{2+}$ and $\mathrm{K}^{+}$content was found to be maximum (Figure $2 \mathrm{C}$ ).

It is evident from Figure 2D that proline (Pro) was higher in plant treated with combined application of $\mathrm{Ca}^{2+}$ and $\mathrm{K}^{+}$. Application of $\mathrm{Ca}^{2+}$ and $\mathrm{K}^{+}$individually on unstressed plants could not bring about a significant change from control in the level of Pro. However, in association with Cd, they improved the quantity of Pro. Under stress conditions, application of $\mathrm{Ca}^{2+}$ gave maximum value for Pro when compared with $\mathrm{K}^{+}$applied alone. The highest level of Pro was found in stressed plants, which were subjected to $\mathrm{Ca}^{2+}$ and $\mathrm{K}^{+}$together.

Figure 3. Ameliorating effect of calcium and potassium on the activity of (A) antioxidant enzymes catalase (CAT) and peroxidase (POD) and (B) superoxide dismutase (SOD) of faba bean plants under Cd stress. Bars followed by the same letters show no statistical difference at $P<0.05$ (Duncan Multiple Range Test). Average of four determinations are presented with bars indicating SE.
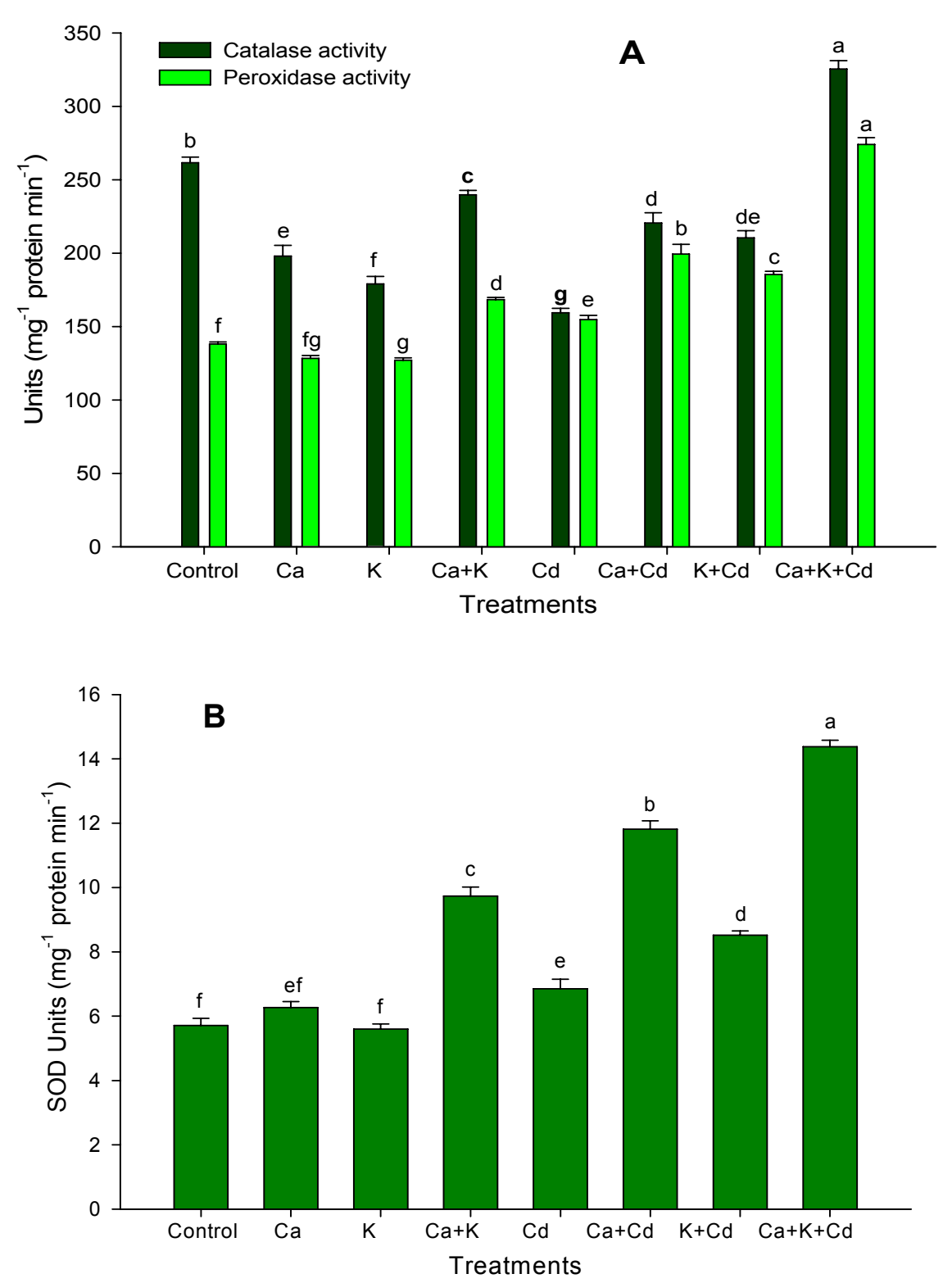
The changes in the activity of antioxidant enzymes, i.e., catalase (CAT), peroxidase (POD), and superoxide (SOD) in faba bean plants exposed to $\mathrm{Ca}^{2+}$ and/or $\mathrm{K}^{+}$under both stress and non-stress conditions are shown in Figures 3A and 3B. Under non-stress conditions, application of $\mathrm{Ca}^{2+}$ and $\mathrm{K}^{+}$ individually decreased the activity of CAT and POD except SOD, but they gave a maximum value for these enzymes' activity when they were applied together. Under $\mathrm{Cd}$ stress, application of $\mathrm{Ca}^{2+}$ individually gave maximum value for POD and SOD, but its effect was at par with $\mathrm{K}^{+}$alone for CAT activity. However, the subsequent application of Cd-stressed plants with the combination of $\mathrm{Ca}^{2+}$ and $\mathrm{K}^{+}$neutralized the adverse effect of $\mathrm{Cd}$ and resulted in considerable improvement in the activities of these three enzymes compared to their individual treatment (Figure 3).

\section{Discussion}

It is well established that accumulation of $\mathrm{Cd}$ in plant tissues may cause a changes in various physiological processes resulting in poor growth, development and productivity of plants $[1,9,36]$. In the present experiment, plants subjected to Cd showed reduced growth in terms of RL, SL, RFW, SFW, RDW and SDW (Figures 1A-1C). The inhibition of growth traits may be due to the consequence of alteration of photosynthesis rate, and uptake and distribution of essential nutrients [37-39]. In the present study, application of $\mathrm{Ca}^{2+}$ and $\mathrm{K}^{+}$alone as well as in combination was efficient to restore the altered plant growth induced by Cd toxicity in Vicia faba. The ameliorating response of both nutrients on plant growth is the consequence of cell elongation and cell division [21,40]; $\mathrm{K}^{+}$acts as catalyst, even under adverse conditions, for many of the enzymatic processes that are necessary for plant growth and development [41]. Khan et al. [11] andSiddiqui et al. [35] reported that presence of $\mathrm{Ca}^{2+}$ in nutrient medium containing $\mathrm{NaCl}$ and $\mathrm{Ni}$, promoted the plant growth. Thus, on the basis of the roles played by these nutrients, we could easily visualize their direct or indirect role in plant growth. This, in turn, could be responsible for the reversal of the altered plant growth induced by Cd stress; these improvements lead the plants with better adaptation under different adverse conditions. Thus, we may postulate that $\mathrm{Ca}^{2+}$ and $\mathrm{K}^{+}$applied together in the present study were more effective in the restoration of altered plant growth characteristics (Figure 1).

The photosynthetic pigments are important macromolecules that are produced by plants, and play a vital role in photosynthesis, which is responsible for plant growth and dry matter production. In the present study, reduction of Chl $a$ and $b$ concentration induced by $\mathrm{Cd}$ stress might be due to the instability of proteins complex, destruction of chloroplast and photosynthetic apparatus [42], inhibition of photosynthetic electron transport chain [43] and the enzymes of Chl biosynthesis such as $\delta$-aminolevulinic acid (ALA) synthase, ALA dehydratase, and porphobilinogenase [44]. Cadmium is involved in the inhibition of heme biosynthesis and chlorophyll synthesis by interacting with sulphydryl requiring enzymes involved in the pathway [45]. Interestingly, from this finding, it is very clear that the application of $\mathrm{Ca}^{2+}$ and/or $\mathrm{K}^{+}$significantly enhance the concentration of these pigments under stress and non-stress conditions. Photosynthetic pigments could be increased due to the maximum presence of leaf- $\mathrm{Ca}^{2+}$ (Figure 2B) that could act as a secondary messenger for cytokinin action in promoting the $\mathrm{Chl}$ biosynthesis; $\mathrm{Ca}^{2+}$ could interact with light in the pathway of $\mathrm{Chl}$ synthesis [46]. Also, $\mathrm{K}^{+}$plays an important role in the formation of photosynthetic pigment by preventing decomposition of newly formed Chl and ALA formation [47]. This result indicates that 
combined application of $\mathrm{Ca}^{2+}$ and $\mathrm{K}^{+}$is associated with tolerance of faba bean plants to $\mathrm{Cd}$ stress by improving the biosynthesis of photosynthetic pigments.

In the present study, an elevated level of MDA concentration in leaves indicates that the plants were subjected to $\mathrm{Cd}$ stress induced lipid peroxidation, which resulted in membrane damage (Figure 2A). This is in accordance with other findings [48,49]. However, the plants that were subjected to $\mathrm{Ca}^{2+}$ and $\mathrm{K}^{+}$alone as well as in combination, exhibited lowest values for MDA content (Figure 2A). This may be due to the antioxidant enzymes activity and Pro accumulation (Figures 2D and 3A, 3B) which has an adaptive significance, as they detoxify the oxygen free radicals and thus reduce the oxidative stress linked membrane deterioration under Cd stress. Also, the inhibition of MDA content may be due to the role of $\mathrm{Ca}^{2+}$ in controlling membrane structure and function by binding to phospholipids that stabilizes lipid bilayers and thus provides structural integrity to cellular membranes [21]. Furthermore, there is the possibility of the involvement of oxidative signal transduction concomitant with the regulation of antioxidant enzymes under stress $[17,50]$. Also, $\mathrm{K}^{+}$plays a key role in reduction of ROS production by reducing activity of $\mathrm{NAD}(\mathrm{P}) \mathrm{H}$ oxidases and maintaining photosynthetic electron transport [41].

The accumulation of $\mathrm{Cd}$ in leaves of faba bean was high under $\mathrm{Cd}$ stress (Figure 2B). However, the accumulation of $\mathrm{Cd}$ was found to be lower in plants subjected to $\mathrm{Ca}^{2+}$ and $\mathrm{K}^{+}$alone as well as in combination (Figure 2C). In this study, the highest accumulation of $\mathrm{Ca}^{2+}$ and $\mathrm{K}^{+}$in leaf was recorded with the combined application of $\mathrm{Ca}^{2+}$ and $\mathrm{K}^{+}$, under stress and non-stress conditions. As evidenced in the present study, Cd caused a decrease in leaf- $\mathrm{Ca}^{2+}$ and $\mathrm{K}^{+}$content in the plants (Figure 2C) which accords with the findings of Suzuki [15] and Umar et al. [51]. In $\mathrm{Ca}^{2+}$ plus $\mathrm{K}^{+}$treated plants, the increased accumulation of $\mathrm{Ca}^{2+}$ and $\mathrm{K}^{+}$may be responsible for the inhibition of uptake and deleterious effects of $\mathrm{Cd}$ in Faba bean plants. The improvement of tolerance of plant to $\mathrm{Cd}$ stress may be due to the presence of $\mathrm{Ca}^{2+}$ that is responsible for active exclusion of toxic $\mathrm{Cd}$ by the formation and excretion of $\mathrm{Cd} / \mathrm{Ca}^{2+}$ containing crystals through the head cells of trichomes [52]. It was also previously reported that $\mathrm{Ca}^{2+}$ was able to alleviate $\mathrm{Cd}$ toxicity, presumably through competition for metal ion influx [15]. Under abiotic stress, plants also require more $\mathrm{K}^{+}$to maintain the photosynthesis because, during this process, reactive oxygen species (ROS) is generated [41]. The increased accumulation of $\mathrm{Ca}^{2+}$ and $\mathrm{K}^{+}$ with the application of $\mathrm{Ca}^{2+}$ and $\mathrm{K}^{+}$alone as well as in combination have been major factors for increasing DW production and plant height because both are important components of many metabolically important compounds and play a vital role in various physiological processes [12].

Pro is not only a universal osmoprotectant, but also acts as an antioxidant as well as a source of energy; also it is considered to be an important biomolecule that has a protective role in tolerance of plant to abiotic stresses $[16,35,53,54]$. Cd stress leads to protein degradation through amino acid metabolism resulting in decreased plant growth [55]. In the present study, under Cd stress, accumulation of Pro was increased as compared to the control (Figure 2D) which is in accordance with the finding of Zhao [54]. However, application of $\mathrm{Ca}^{2+}$ and $\mathrm{K}^{+}$individually as well as in combination was found to be effective to enhance further accumulation of Pro under stress and non-stress conditions (Figure 2D). The enhanced accumulation of Pro in leaves may represent a major biochemical adaptation, membrane stabilization and ROS scavenger [16,30,35,53,56]. Free Pro acts as an antioxidant in Cd-stressed cells and Pro levels are correlated with the GSH redox state and MDA levels in heavy metal-treated algae [57]. This result agrees with the finding of Siddiqui et al. [16], who reported that the production of Pro was higher in $\mathrm{Ca}^{2+}$-exposed plants under heavy metal stress. 
The antioxidant system is one of the important defense mechanisms of plants, through which plants perform normally under different environmental conditions by scavenging ROS. In this experiment, antioxidant enzymes such as POD and SOD except CAT, increased slightly under Cd stress (Figures $3 \mathrm{~A}, 3 \mathrm{~B})$. However, application of $\mathrm{Ca}^{2+}$ and $\mathrm{K}^{+}$significantly enhanced the activity of all enzymes; the fact that the maximum increase in the activity of these enzymes was found in plants might be due to the combined application of $\mathrm{Ca}^{2+}$ and $\mathrm{K}^{+}$(Figures 2A, 2B). The increased activity of antioxidant enzymes may be due to the active role of $\mathrm{K}^{+}$, which activates more than 50 enzymes [14]. Under stress, $\mathrm{K}^{+}$plays important role in the synthesis of protein by participating in polypeptide synthesis in the ribosomes, since that process requires a high concentration of $\mathrm{K}^{+}$[58]. Tripathi et al. [59] reported that proteins, such as thioredoxin, glutaredoxin, cyclophilin, among others, are known to facilitate the regeneration of the reduced (catalytically active) form of peroxiredoxins that play an important role in reducing the ROS formation in plants under biotic and abiotic stress. Also, $\mathrm{Ca}^{2+}$ acts as a secondary messenger of external stimuli, and stimulates calmodulin-like proteins that interact with $\mathrm{Ca}^{2+}$ ions. Changing their conformation in response to $\mathrm{Ca}^{2+}$ binding, calmodulin proteins regulate a variety of mechanisms, including ion transport, gene regulation, cell motility, growth, proliferation, apoptosis and stress tolerance that coordinate, at least in part, the plant response to $\mathrm{Cd}$ [60-62]. The $\mathrm{Ca}^{2+}$ might be responsible for decreased thiobarbutric acid and hydrogen peroxide content, as the unique importance of $\mathrm{Ca}^{2+}$ for stabilizing membranes is well established [21]. Khan et al. [17] and Siddiqui et al. [16] reported that application of $\mathrm{Ca}^{+2}$ was found to be effective in improving the tolerance of plant to abiotic stress by improving antioxidant systems. Thus, these results indicate that the improved activity of antioxidative enzymes due to the combined application of $\mathrm{Ca}^{2+}$ and $\mathrm{K}^{+}$ resulted in an increase in the capacity of various defense mechanisms and also improvement in various physiological and biochemical processes leading to the tolerance of the plant to $\mathrm{Cd}$ stress.

\section{Experimental Section}

\subsection{Plant Cultures and Treatments}

To meet the objectives mentioned in the introduction, the response of fabe bean (Vicia faba L.) to $\mathrm{Ca}^{2+}$ and $\mathrm{K}^{+}$under $\mathrm{Cd}$ toxicity were studied by conducting a greenhouse pot experiment at the Department of Botany and Microbiology, King Saud University, Riyadh. Seeds of faba bean (cv. TARA) were obtained from a local market in Riyadh, Saudi Arabia. Healthy seeds were surface sterilized by using $1 \%$ sodium hypochlorite for $10 \mathrm{~min}$ then vigorously rinsed with sterilized double distilled water (DDW) before sowing. The seeds were sown in plastic pots $(25 \mathrm{~cm}$ in diameter, $25 \mathrm{~cm}$ height) filled with perlite and supplied with Raukura's nutrient solution [63]. The pots were arranged in a simple randomized design in the Glasshouse (Department of Botany and Microbiology, King Saud University, Riyadh, KSA) with a single factor and four replicates. The pots were covered with black plastic to reduce evaporation. One week after sowing, seedlings were thinned so that each pot contained healthy plants of uniform size. Pots were irrigated every two days with DDW (100 mL) to keep the perlite moist. $\mathrm{Ca}$ and $\mathrm{K}$ treatments were initiated 10 days after germination as follows: (i) $\mathrm{Ca}_{0}+\mathrm{K}_{0}+\mathrm{Cd}_{0}$ (control); (ii) $\mathrm{Ca}_{40} \mathrm{mM}+\mathrm{K}_{0}+\mathrm{Cd}_{0}$; (iii) $\mathrm{Ca}_{0}+\mathrm{K}_{6} \mathrm{mM}+\mathrm{Cd}_{0}$; (iv) $\mathrm{Ca}_{40} \mathrm{mM}+\mathrm{K}_{6} \mathrm{mM}+$ $\mathrm{Cd}_{0}$; (v) $\mathrm{Ca}_{0}+\mathrm{K}_{0}+\mathrm{Cd}_{200} \mu \mathrm{M}$; (vi) $\mathrm{Ca}_{40} \mathrm{mM}+\mathrm{K}_{0}+\mathrm{Cd}_{200} \mu \mathrm{M}$; (vii) $\mathrm{Ca}_{0}+\mathrm{K}_{6} \mathrm{mM}+\mathrm{Cd}_{200} \mu \mathrm{M}$; 
(viii) $\mathrm{Ca}_{40} \mathrm{mM}+\mathrm{K}_{6} \mathrm{mM}+\mathrm{Cd}_{200} \mu \mathrm{M}$. The sources of $\mathrm{Ca}$ and $\mathrm{K}$ were calcium chloride and potassium chloride, respectively. Plants were sampled on the seventh day after treatment to assess their growth characteristics SL plant $^{-1}$, RL plant ${ }^{-1}$, SFW plant ${ }^{-1}$, and RFW plant ${ }^{-1}$, SDW plant ${ }^{-1}$, RDW plant ${ }^{-1}$ and physiological attributes [Chl $a$ and $\mathrm{Chl} b$, concentrations of $\mathrm{Ca}^{2+}, \mathrm{K}^{+}$, Pro and MDA; and activity of CAT, POD and SOD].

\subsection{Plant Growth Characteristics}

Shoot length and RL were measured using a meter scale after removal from the pots. After recording FW with balance, plants were placed in a $60{ }^{\circ} \mathrm{C}$ oven for $48 \mathrm{~h}$ and then were weighed for DW.

\subsection{Physiological and Biochemical Parameters}

\subsubsection{Chemical Content of Leaves}

All the chemical reagents used in this procedure were of analytical grade. Absorbances were determined using a UV-VIS spectrophotometer, unless otherwise specified. Chlorophyll was extracted from fresh leaves using the DMSO method of Barnes et al. [64]. Chl $a$ and Chl $b$ concentrations were calculated based on the absorbance of the extract at 663.8 and $646.8 \mathrm{~nm}$.

To determine $\mathrm{Ca}, \mathrm{K}$ and $\mathrm{Cd}$ concentrations, we followed the digestion approach of Zheljazkov and Nielson [65] as modified by Hseu [66]. A leaf sample $(0.5 \mathrm{~g})$ was placed in a $250 \mathrm{~mL}$ digestion tube, and $10 \mathrm{~mL}$ of 2:1 concentrated nitric acid: perchloric acid was added. Samples were heated for $45 \mathrm{~min}$ at $90{ }^{\circ} \mathrm{C}$ for $2-3 \mathrm{~h}$ until a clear solution was obtained. At intervals, $5 \mathrm{~mL}$ of concentrated nitric acid: perchloric acid with hydrogen peroxide were added to the sample (at least three times), and the digestion continued until the volume was reduced to about $1 \mathrm{~mL}$. The interior walls of the tube were washed down with a little DDW and the tubes were swirled throughout the digestion to keep the walls clean and prevent loss of the samples. After cooling, $5 \mathrm{~mL}$ of $1 \% \mathrm{HNO}_{3}$ was added to each sample. Thereafter, the solution was filtered through Whatman No. 42 filter paper and $<0.45 \mu \mathrm{m}$ millipore filter paper. The filtrate was diluted to a total of $25 \mathrm{~mL}$ with distilled water. After dilution, the concentrations of $\mathrm{Ca}$ and $\mathrm{K}$ were determined by using with an atomic absorption spectrometer (Model 300, Perkin-Elmer, Waltham, MA, USA) and Cd was determined with the help of Inductively Coupled Plasma Optical Emission Spectroscope (Model iCAP6000, Thermo-Scientific, Thermo-Fisher Scientific, Waltham, MA, USA).

Proline concentration was determined spectrophotometrically by adopting the ninhydrin method of Bates et al. [67]. We first homogenized $300 \mathrm{mg}$ of fresh leaf samples in sulphosalicylic acid, then added $2 \mathrm{~mL}$ each of acid ninhydrin and glacial acetic acid. The samples were heated at $100{ }^{\circ} \mathrm{C}$. The mixture was extracted with toluene and the free toluene was quantified at $528 \mathrm{~nm}$ using L-proline as a standard.

Malondialdehyde (MDA) content was determined according to the method of Heath and Packer [68]. Leaves were weighed and homogenates containing 10\% trichloroacetic acid (TCA) and $0.65 \%$ 2-thiobarbituric acid were heated at $95{ }^{\circ} \mathrm{C}$ for $60 \mathrm{~min}$ then cooled to room temperature and 
centrifuged at $10,000 \times g$ for $10 \mathrm{~min}$. The absorbance of the supernatant was read at $532 \mathrm{~nm}$ and $600 \mathrm{~nm}$ against a reagent blank.

\subsubsection{Enzyme Activity}

To determine the enzymatic activities of the antioxidant proteins, a crude enzyme extract was prepared by homogenizing $500 \mathrm{mg}$ of leaf tissue in extraction buffer containing $0.5 \%$ Triton X-100 and $1 \%$ polyvinylpyrrolidone in $100 \mathrm{mM}$ potassium phosphate buffer $(\mathrm{pH} 7.0)$ using a chilled mortar and pestle. The homogenate was centrifuged at $15,000 \times g$ for $20 \mathrm{~min}$ at $4{ }^{\circ} \mathrm{C}$. The supernatant was used for the enzymatic assays described below. All enzyme activities were expressed as units $\mathrm{mg}^{-1}$ protein $\min ^{-1}$.

We used the method of Chance and Maehly [69] to determine POD (E.C. 1.11.1.7) activity by using $5 \mathrm{~mL}$ of an assay mixture containing phosphate buffer ( $\mathrm{pH} \mathrm{6.8),} 50 \mathrm{M}$ of pyrogallol, $50 \mathrm{mM}$ of $\mathrm{H}_{2} \mathrm{O}_{2}$, and $1 \mathrm{~mL}$ of the enzyme extract diluted $20 \times$. This was incubated for $5 \mathrm{~min}$ at $25{ }^{\circ} \mathrm{C}$, after which the reaction was stopped by adding $0.5 \mathrm{~mL}$ of $5 \%(\mathrm{v} / \mathrm{v}) \mathrm{H}_{2} \mathrm{SO}_{4}$. The amount of purpurogallin formed was determined by measuring absorbance at $420 \mathrm{~nm}$. A unit of peroxidase activity was the amount of purpurogallin formed per mg protein per minute.

Aebi [70] method was used to measure CAT (EC 1.11.1.6) activity. The decomposition of $\mathrm{H}_{2} \mathrm{O}_{2}$ was monitored by the decrease in absorbance at $240 \mathrm{~nm}$. For the assay, a $50 \mathrm{mM}$ phosphate buffer (pH 7.8) and $10 \mathrm{mM} \mathrm{H}_{2} \mathrm{O}_{2}$ were used.

The activity of SOD (EC 1.15.1.1) was determined by measuring its ability to inhibit the photoreduction of nitro blue tetrazolium (NBT) according to the methods of Giannopolitis and Ries [71]. The reaction solution $(3 \mathrm{~mL})$ contained $50 \mu \mathrm{mol} \mathrm{NBT}, 1.3 \mu \mathrm{mol}$ riboflavin, $13 \mathrm{mmol}$ methionine, $75 \mathrm{nmol}$ EDTA, $50 \mathrm{mmol}$ phosphate buffer ( $\mathrm{pH} 7.8$ ), and 20 to $50 \mu \mathrm{L}$ enzyme extract. The reaction solution was irradiated under a bank of fluorescent lights at $75 \mu \mathrm{mol} \cdot \mathrm{m}^{-2} \cdot \mathrm{s}^{-1}$ for $15 \mathrm{~min}$. The absorbance at $560 \mathrm{~nm}$ was read against a blank (non-irradiated reaction solution). One unit of SOD activity was defined as the amount of enzyme that inhibited $50 \%$ of NBT photoreduction.

\subsection{Statistical Analysis}

Each pot was treated as one replicate and all the treatments were repeated four times. The data were analyzed statistically with SPSS-17 statistical software (SPSS Inc., Chicago, IL, USA). Means were statistically compared by Duncan's Multiple Range Test (DMRT) at the $p<0.05 \%$ level.

\section{Conclusions}

In summary, results presented above confirm the importance of $\mathrm{Ca}^{2+}$ and/or $\mathrm{K}$ application in the detoxification of $\mathrm{Cd}$ toxicity. These results clearly show that application of $\mathrm{Ca}^{2+}$ and/or $\mathrm{K}^{+}$decreased in MDA and Cd contents, and increased in photosynthetic pigment, Pro, antioxidant enzymes activity (CAT, POD and SOD) and accumulation of nutrients $\left(\mathrm{Ca}^{2+}\right.$ and $\left.\mathrm{K}^{+}\right)$may be responsible for better growth in terms of RL, SL, RFW, SFW that were responsible for enhanced dry matter production under $\mathrm{Cd}$ stress. Therefore, inclusion of $\mathrm{Ca}^{2+}$ and/or $\mathrm{K}^{+}$in growth medium could be an adequate 
strategy to alleviate the harmful effects of heavy metal stress and to enhance plant metabolism to perform better under normal as well as different environmental conditions.

\section{Acknowledgements}

The financial support given by the Deanship of Scientific Research of King Saud University, Riyadh, KSA to the Research Group No. RGPVPP-153 is gratefully acknowledged.

\section{Conflict of Interest}

The authors declare that they have no conflict of interest.

\section{References}

1. Sanitá di Toppi, L.; Gabbrielli, R. Response to cadmium in higher plants. Environ. Exp. Bot. 1999, 41, 105-130.

2. Yang, X.E.; Long, X.X.; Ye, H.B.; He, Z.L.; Calvert, D.V.; Stoffella, P.J. Cadmium tolerance and hyperaccumulation in a new $\mathrm{Zn}$ hyperaccumulating plant species (Sedum alfredii Hance). Plant Soil 2004, 259, 181-189.

3. Leita, L.; de Nobili, M.; Cesco, C.; Mondini, C. Analysis of intercellular cadmium forms in roots and leaves of bush bean. J. Plant Nutr. 1996, 19, 527-533.

4. Mishra, S.; Srivastava, S.; Tripathi, R.D.; Govindarajan, R.; Kuriakose, S.V.; Prasad, M.N.V. Phytochelatin synthesis and response of antioxidants during cadmium stress in Bacopa monnieri L. Plant Physiol. Biochem. 2006, 44, 25-37.

5. Das, P.; Samantaray, S.; Rout, G.R. Studies on cadmium toxicity in plants: A review. Environ. Pollut. 1997, 98, 29-36.

6. Clarkson, D.T.; Luttge, U. Mineral nutrition: Divalent cations, transport and compartmentation. Progr. Bot. 1989, 51, 93-112.

7. Rivetta, A.; Negrini, N.; Cocucci, M. Involvement of $\mathrm{Ca} 2+$-calmodulin in $\mathrm{Cd}^{2+}$ toxicity during the early phases of radish (Raphanus sativus L.) seed germination. Plant Cell Environ. 1997, 20, 600-608.

8. Sandalio, L.M.; Dalurzo, H.C.; Gómez, M.; Romero-Puertas, M.C.; del Río, L.A. Cadmium-induced changes in the growth and oxidative metabolism of pea plants. J. Exp. Bot. 2001, 52, 2115-2126.

9. Rodríguez-Serrano, M.; Romero-Puertas, M.C.; Pazmiño, D.M.; Testillano, P.S.; Risueño, M.C.; del Río, L.A.; Sandalio, L.M. Cellular response of pea plants to cadmium toxicity: Cross talk between reactive oxygen species, nitric oxide, and calcium. Plant Physiol. 2009, 150, 229-243.

10. Chen, S.; Sun, L.; Sun, T.; Chao, L.; Guo, G. Interaction between cadmium, lead and potassium fertilizer $\left(\mathrm{K}_{2} \mathrm{SO}_{4}\right)$ in a soil-plant system. Environ. Geochem. Health 2007, 29, 435-446.

11. Leigh, R.A.; Jones, R.G.W. A hypothesis relating critical potassium concentrations for growth to the distribution and functions of this ion in the plant-cell. New Phytol. 1984, 97, 1-13.

12. Marschner, H. Mineral Nutrition of Higher Plants, 2nd ed.; Academic Press: London, UK, 2002. 
13. Mengel, K. Potassium. In Handbook of Plant Nutrition; Barker, A.V., Pilbeam, D.J., Eds.; CRC Press: Boca Raton, FL, USA, 2007; pp. 91-120.

14. Bhandal, I.S.; Malik, C.P. Potassium estimation, uptake and its role in the physiology and metabolism of flowering plants. Int. Rev. Cytol. 1988, 110, 205-254.

15. Suzuki, N. Alleviation by calcium of cadmium-induced root growth inhibition in Arabidopsis seedlings. Plant Biotech. 2005, 22, 19-25.

16. Siddiqui, M.H.; Al-Whaibi, M.H.; Basalah, M.O. Interactive effect of calcium and gibberellin on nickel tolerance in relation to antioxidant systems in Triticum aestivum L. Protoplasma 2011, 248, 503-511.

17. Khan, M.N.; Siddiqui, M.H.; Mohammad, F.; Naeem, M.; Khan, M.M.A. Calcium chloride and gibberellic acid protect linseed (Linum usitatissimum L.) from $\mathrm{NaCl}$ stress by inducing antioxidative defence system and osmoprotectant accumulation. Acta Physiol. Plant. 2010, 32, 121-132.

18. Antosiewicz, D.M., Hennig, J. Overexpression of LCT1 in tobacco enhances the protective action of calcium against cadmium toxicity. Environ. Pollut. 2004, 129, 237-245.

19. Jáuregui-Zùñiga, D.; Ferrer, M.A.; Calderón, A.A.; Muñoz, R.; Moreno, A. Heavy metal stress reduces the deposition of calcium oxalate crystals in leaves of Phaseolus vulgaris. J. Plant Physiol. 2005, 162, 1183-1187.

20. Dayod, M.; Tyerman, S.D.; Leigh, R.A.; Gilliham, M. Calcium storage in plants and the implications for calcium biofortification. Protoplasma 2010, 247, 215-231.

21. Hirschi, K.D. The calcium conundrum. Both versatile nutrient and specific signal. Plant Physiol. 2004, 136, 2438-2442.

22. Plieth, C. Plant calcium signaling and monitoring: Pros and cons and recent experimental approaches. Protoplasma 2001, 218, 1-23.

23. White, P.J.; Broadley, M.R. Calcium in plants. Ann. Bot. 2003, 92, 487-511.

24. Handley, R.; Metwally, A.; Overstreet, R. Effects of Ca upon metabolic and nonmetabolic uptake of $\mathrm{Na}$ and $\mathrm{Rb}$ by root segments of Zea mays. Plant Physiol. 1965, 40, 513-520.

25. Elzam, O.E.; Hodges, T.K. Calcium inhibition of potassium absorption in corn roots. Plant Physiol. 1967, 42, 1483-1488.

26. Rains, D.W.; Epstein, E. Sodium absorption by barley roots: Its mediation by mechanism 2 of alkali cation transport. Plant Physiol. 1967, 42, 319-323.

27. Van Steveninck, R.F.M. The significance of calcium on the apparent permeability of cell membranes and the effects of substitution with other divalent ions. Physiol. Plant. 1965, 18, 54-69.

28. Epstein, E. The essential role of calcium in selective cation transport by plant cells. Plant Physiol. 1961, 36, 437-444.

29. Jakobsen, S.T. Interaction between plant Nutrients: III. Antagonism between potassium, magnesium and calcium. Acta Agric. Scand. Sect. B Soil Plant 1993, 43, 1-5.

30. Siddiqui, M.H.; Khan, M.N.; Mohammad, F.; Khan, M.M.A. Role of nitrogen and gibberellins (GA3) in the regulation of enzyme activities and in osmoprotectant accumulation in Brassica juncea L. under salt stress. J. Agron. Crop Sci. 2008, 194, 214-224. 
31. Malvi, U.R. Interaction of micronutrients with major nutrients with special reference to potassium. Karnataka J. Agric. Sci. 2011, 24, 106-109.

32. Oliver, D.P.; Schultz, J.E.; Tiller, K.G.; Merry, R.H. The effect of crop rotations and tillage practices on cadmium concentration in wheat grain. Agric. Res. 1993, 44, 1221-1234.

33. Nie, J.H.; Liu, X.M.; Wang, Q.R. Effects of nutrient elements on the lead uptake by hyperaccumulators. Ecol. Environ. 2004, 13, 306-309.

34. Tu, C.; Zheng, C.R.; Chen, H.M. Effect of applying chemical fertilizers on forms of lead and cadmium in red soil. Chemosphere 2000, 41, 133-138.

35. Siddiqui, M.H.; Mohammad, F.; Khan, M.M.A.; Al-Whaibi, M.H. Cumulative effect of nitrogen and sulphur on Brassica juncea L. genotypes under $\mathrm{NaCl}$ stress. Protoplasma 2012, 249, 139-153.

36. Perfus-Barbeoch, L.; Leonhardt, N.; Vavasseur, A.; Forestier, C. Heavy metal toxicity: Cadmium permeates through calcium channels and disturbs the plant water status. Plant J. 2002, 32, 539-548.

37. Benavides, M.P.; Gallego, S.M.; Tomaro, M. Cadmium toxicity in plants. Braz. J. Plant Physiol. 2005, 17, 21-34.

38. Dong, J.; Wu, F.; Zhang, G. Effect of cadmium on growth and photosynthesis of tomato seedlings. Zhejiang Univ. Sci. B 2005, 6, 974-980.

39. Kurtyka, R.; Małkowski, E.; Kita, A.; Karcz, W. Effect of calcium and cadmium on growth and accumulation of cadmium, calcium, potassium and sodium in maize seedlings. Polish J. Environ. Stud. 2008, 17, 51-56.

40. Parmelee, J.T.; Beebe, D.C. Decreased membrane permeability to potassium is responsible for the cell volume increase that drives lens fiber cell elongation. J. Cell Physiol. 1988, 134, 491-496.

41. Cakmak, I. The role of potassium in alleviating detrimental effects of abiotic stresses in plants. J. Plant Nutr. Soil Sci. 2005, 168, 521-530.

42. Vassilev, A.; Iordanov, I.; Chakalova, E.; Kerin, V. Effect of cadmium stress on growth and photosynthesis of young barley $(H$. vulgare L.) plants. 2. Structural and functional changes in the photosynthetic apparatus. Bujg. J. Plant Physiol. 1995, 21, 12-21.

43. Mohanty, N.; Vass, I.; Demeter, S. Impairment of photosystem II activity at the level of secondary quinine acceptor in chloroplasts treated with cobalt, nickel and zinc ions. Physiol. Plant. 1989, 76, 386-390.

44. Shalygo, N.V.; Kolensikova, N.V.; Voronetskaya, V.V.; Averina, N.G. Effects of $\mathrm{Mn}^{2+}, \mathrm{Fe}^{2+}$, $\mathrm{Co}^{2+}$ and $\mathrm{Ni}^{2+}$ on chlorophyll accumulation and early stages of chlorophyll formation of greening barley seedling. Russ. J. Plant Physiol. 1999, 46, 496-501.

45. Pandey, S.; Gupta, K.; Mukherjee, A.K. Impact of cadmium and lead on Catharanthus roseus-A phytoremediation study. J. Environ. Biol. 2007, 28, 655-662.

46. Lechowski, Z.; Bialczyk, J. Calcium mediated cytokinin action on chlorophyll synthesis in isolated embryo of Scots pine. Biol. Plant. 1993, 35, 53-62.

47. Tanaka, A.; Tsuji, H. Effects of calcium on chlorophyll synthesis and stability in the early phase of greening in cucumber cotyledons. Plant Physiol. 1980, 65, 1211-1215.

48. Kórzyńska-Polit, E.; Drążkiewicz, M.; Krupa, Z. Lipid peroxidation and antioxidative response in Arabidopsis thaliana exposed to cadmium and copper. Acta Physiol. Plant 2010, 32, 169-175. 
49. Liu, Z.; Chen, W.; He, X. Cadmium-induced changes in growth and antioxidative mechanisms of a medicine plant (Lonicera japonica Thunb.). J. Med. Plants Res. 2011, 5, 1411-1417.

50. McAinsh, M.R.; Clayton, H.; Mansfield, T.A.; Hetherington, A.M. Changes in stomatal behavior and guard cell cytosolic free calcium in response to oxidative stress. Plant Physiol. 1996, 111, 1031-1042.

51. Umar, S.; Diva, I.; Anjum, N.A.; Iqbal, M. Potassium nutrition reduces cadmium accumulation and oxidative burst in mustard (Brassica campestris L.). Electron. Int. Fertil. Corresp. 2008, 16, $6-10$.

52. Choi, Y.E.; Harada, E.; Wada, M.; Tsuboi, H.; Morita, Y.; Kusano, T.; Sano, H. Detoxification of cadmium in tobacco plants: Formation and active excretion of crystals containing cadmium and calcium through trichomes. Planta 2001, 213, 45-50.

53. Matysik, J.; Alia, B.B.; Mohanty, P. Molecular mechanisms of quenching of reactive oxygen species by proline under stress in plants. Curr. Sci. 2002, 82, 525-532.

54. Zhao, Y. Cadmium accumulation and antioxidative defenses in leaves of Triticum aestivum L. and Zea mays L. African J. Biotech. 2011, 10, 2936-2943.

55. Dinakar, N.; Nagajyothi, P.C.; Suresh, S.; Udaykiran, Y.; Damodharam, T. Phytotoxicity of cadmium on protein, proline and antioxidant enzyme activities in growing Arachis hypogaea L. seedlings. J. Environ. Sci. 2008, 20, 199-206.

56. Bandurska, H. Proline accumulation during hardening and its involvement in reducing membrane injuries in leaves subjected to severe osmotic stress. Acta Physiol. Plant. 2001, 23, 483-490.

57. Siripornadulsil, S.; Traina, S.; Verma, D.P.S.; Sayre, R.T. Molecular mechanisms of proline-mediated tolerance to toxic heavy metals in transgenic microalgae. Plant Cell 2002, 14, 2837-2847.

58. Jones, R.G.; Pollard, A. Proteins, Enzymes and Inorganic Ions. In Inorganic Plant Nutrition; Läuchli, A., Bieleski, R.L., Eds.; Springer: New York, NY, USA, 1983; pp. 528-562.

59. Tripathi, B.N.; Bhatt, I.; Dietz, K.J. Peroxiredoxins: A less studied component of hydrogen peroxide detoxification in photosynthetic organisms. Protoplasma 2009, 235, 3-15.

60. Yang, T.; Poovaiah, B.W. Calcium/calmodulin-mediated signal network in plants. Trends Plant Sci. 2003, 8, 505-512.

61. Park, H.Y.; Kim, S.A.; Korlach, J.; Rhoades, E.; Kwok, L.W.; Zipfel, W.R.; Waxham, M.N.; Webb, W.W.; Pollack. L. Conformational changes of calmodulin upon $\mathrm{Ca}^{2+}$ binding studied with a microfluidic mixer. Proc. Nat. Acad. Sci. USA 2008, 105, 542-547.

62. DalCorso, G.; Farinati, S.; Furini, A. Regulatory networks of cadmium stress in plants. Plant Signal. Behav. 2010, 5, 663-667.

63. Smith, G.S.; Johnston, C.M.; Cornforth, I.S. Comparison of nutrient solutions for growth of plants in sand culture. New Phytol. 1983, 94, 537-548.

64. Barnes, J.D.; Balaguer, L.; Manrique, E.; Elvira, S.; Davison, A.W. A reappraisal of the use of DMSO for the extraction and determination of chlorophylls a and $\mathrm{b}$ in lichens and higher plants. Environ. Exp. Bot. 1992, 32, 85-100.

65. Zheljazkov, V.D.; Nielson, N.E. Effect of heavy metals on peppermint and cornmint. Plant Soil 1996, 178, 59-66. 
66. Hseu, Z.Y. Evaluating heavy metal contents in nine composts using four digestion methods. Bioresour. Technol. 2004, 95, 53-59.

67. Bates, L.S.; Waldren, R.P.; Teare, I.D. Rapid determination of free proline for water-stress studies. Plant Soil 1973, 39, 205-207.

68. Heath, R.L.; Packer, L. Photoperoxidation in isolated chloroplasts. I. Kinetics and stoichiometry of fatty acid peroxidation. Arch. Biochem. Biophys. 1968, 125, 189-198.

69. Chance, B.; Maehly, A.C. Assay of catalase and peroxidases. Methods Enzymol. 1955, 2, 764-775.

70. Aebi, H. Catalase in vitro. Methods Enzymol. 1984, 105, 121-126.

71. Giannopolitis, C.N.; Ries, S.K. Superoxide dismutases: I. Occurrence in higher plants. Plant Physiol. 1977, 59, 309-314.

(C) 2012 by the authors; licensee MDPI, Basel, Switzerland. This article is an open access article distributed under the terms and conditions of the Creative Commons Attribution license (http://creativecommons.org/licenses/by/3.0/). 